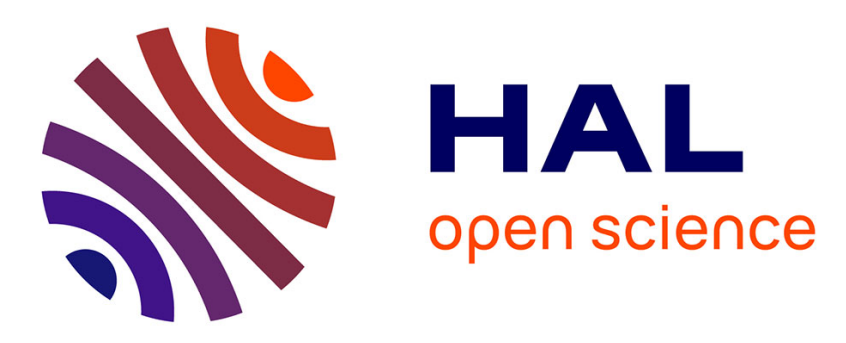

\title{
Effect of microwaves on the in situ hydrodistillation of four different Lamiaceae
}

\author{
Arianna Binello, Laura Orio, Giuseppe Pignata, Silvana Nicola, Farid \\ Chemat, Giancarlo Cravotto
}

\section{- To cite this version:}

Arianna Binello, Laura Orio, Giuseppe Pignata, Silvana Nicola, Farid Chemat, et al.. Effect of microwaves on the in situ hydrodistillation of four different Lamiaceae. Comptes Rendus. Chimie, 2014, 17, pp.181-186. 10.1016/j.crci.2013.11.007 . hal-02641515

\section{HAL Id: hal-02641515 https://hal.inrae.fr/hal-02641515}

Submitted on 28 May 2020

HAL is a multi-disciplinary open access archive for the deposit and dissemination of scientific research documents, whether they are published or not. The documents may come from teaching and research institutions in France or abroad, or from public or private research centers.
L'archive ouverte pluridisciplinaire HAL, est destinée au dépôt et à la diffusion de documents scientifiques de niveau recherche, publiés ou non, émanant des établissements d'enseignement et de recherche français ou étrangers, des laboratoires publics ou privés. 


\title{
Effect of microwaves on the in situ hydrodistillation of four different Lamiaceae
}

\author{
Arianna Binello ${ }^{a}$, Laura Orio ${ }^{a}$, Giuseppe Pignata ${ }^{b}$, Silvana Nicola ${ }^{b}$, Farid \\ Chemat $^{\mathrm{c}}$, Giancarlo Cravotto ${ }^{\mathrm{a}, *}$ \\ ${ }^{a}$ Dipartimento di Scienza e Tecnologia del Farmaco, University of Turin, via P. Giuria 9, 10235 Torino, Italy \\ ${ }^{\mathrm{b}}$ Dipartimento AGRIFORFOOD, VEGMAP, University of Turin, via Leonardo da Vinci, 44, 10095 Grugliasco, TO, Italy \\ ' Université d'Avignon et Pays de Vaucluse, INRA, UMR 408, GREEN Extraction Team, 84000 Avignon, France
}

Keywords:

In situ microwave-generated

hydrodistillation

Hydrodistillation

Microwave hydrodiffusion and gravity

Lamiaceae

Essential oils
A B S T R A C T

The development of alternative techniques to classic hydrodistillation (HD) has been prompted because of the drawbacks of the more traditional technique. These drawbacks include: partial thermal degradation, high energy consumption and the fact that it is a time-consuming process. In situ microwave-generated hydrodistillation (MGH) and microwave hydrodiffusion and gravity (MHG) are suitable methods which may improve the preparation of essential oils. In this work, we report a comparison study of HD, MGH and MHG used in the extraction of four plant species cultivated in Piedmont (Italy): lavender, oregano, basil and sage. Both microwave-assisted procedures gave excellent results; in particular the essential oils obtained under MHG were very similar to those obtained with $\mathrm{HD}$. In MGH, the polarity and the physico-chemical properties of the extracted compounds caused bigger differences in essential oil composition.

\section{Introduction}

The use of essential oils (EO) in the food and pharmaceutical industries has a long history. EO are a complex mixture of secondary metabolites, including terpenes, phenolics and alcohols. Although alternative processes are known, the vast majority of EO are produced by hydrodistillation under vapor steam. Hydrodistillation (HD) is a simple form of steam distillation, which is often used to isolate non-water soluble, high boiling point and natural products. In HD, botanicals are fully submerged in water, producing a "soup", whose steam contains the aromatic compounds. The EO of the distillate are then extracted and analyzed. This is the most ancient method of distillation and the most versatile. The long treatment time and local overheating may cause partial degradation or hydrolysis resulting in EO with a burnt note and the loss of

\footnotetext{
* Corresponding author.

E-mail address: giancarlo.cravotto@unito.it (G. Cravotto).
}

more volatile compounds [1]. HD seems to work best for powders (i.e., spice powders, ground wood, etc.) and very tough materials like roots, wood or nuts.

Over the last few years, more laboratories have successfully applied microwave-assisted extraction (MAE) [2,3] and in situ microwave-generated hydrodistillation (MGH) [4], which are both now well recognized as innovative green and efficient techniques [5]. Dielectric heating is a non-classical energy source that is capable of reducing extraction times because of its selective volumetric heating that also gives excellent product quality [6,7]. In MGH, molecular motion within polar or ionic components causes heating. The rapid delivery of energy to the sample allows the temperature to rise rapidly in the plant cell and, after cell membrane collapse, the essential oil is released and carried away by the water vapor; the condensation and collection of the product, followed by EO isolation conclude the extractive operation [8]. Another green technique for EO extraction, microwave hydrodiffusion and gravity (MHG) developed by Chemat et al. [9,10], combines microwave heating and earth's gravity at 
Version définitive du manuscrit publiée dans / Final version of the manuscript published in :

Comptes Rendus Chimie (2014),vol 17, p 181-1.86, DOI: 10.1016/j.crci.2013.11.007

Journal homepage: http://www.sciencedirect.com

atmospheric pressure. Thanks to hydrodiffusion and earth's gravity, the extract can drip out from the microwave reactor, falling through a perforated Pyrex disc and is cooled by a cooling system; water and essential oils are collected and easily separated into a suitable vessel, traditionally called the "Florentine flask".

The present work deals with Lamiaceae, cosmopolitan plants containing about 236 genera and 6900 to 7200 species. These plants are frequently aromatic in all parts and also are widely cultivated for decorative foliage or food use. Lavender, Greek oregano, sweet basil and sage contain fine essential oils used in cosmetics, food and pharmaceuticals, and were thus chosen for this study. In a previous work [11], we reported the results obtained with HD and MGH in the extraction of fresh and dry mint leaves. We herein report the results of a new comparison study on the effectiveness of MGH and MHG on four different genotypes (dry material): Lavandula angustifolia Mill. (lavender), Origanum vulgare L. ssp. hirtum (Link) Ietswaart (Greek oregano), Ocimum basilicum L. (sweet basil), Salvia officinalis L. ssp. Lavandulifolia (sage). Yields and the chemical profiles of the main components are described and commented on.

\section{Results and discussion}

\subsection{Extraction yield and time}

The percentage of dry plant material (\% DM) is reported in Table 1. Oregano and basil leaves had lower dry matter levels than the leaves of the other genotypes tested, probably because Origanum vulgare and Ocimum basilicum have more tender leaves than the other species; in particular, oregano DM was twice as high as in previous experiments when leaves were harvested from much older plants [12]. Salvia officinalis L. ssp. Lavandulifolia plants were harvested at pre-blossoming stage and their DM were in line with previous experiments [13].

HD, MGH and MHG EO yields are listed in Table 2. No striking differences in the three methods were found in oil yield for Ocimum basilicum. HD and MHG of Origanum vulgare and Salvia officinalis gave the best results, while MGH gave a better yield for Lavandula angustifolia distillation, probably due to the presence of the flowers. Considering the extraction times, MHG seems to be more efficient than $\mathrm{HD}$, which is the reference method in EO extraction.

\subsection{Composition of essential oils}

The EO extracted by MGH, MHG and HD are all rather similar in their composition. In general, a similar number

Table 1

Dry matter percentage (DM).

\begin{tabular}{ll}
\hline & DM \\
\hline Lavandula angustifolia Mill. (leaves + flowers) & 24.85 \\
Origanum vulgare L. ssp. hirtum (Link) Ietswaart (leaves) & 12.65 \\
Ocimum basilicum L. (leaves) & 14.43 \\
Salvia officinalis L. ssp. lavandulifolia (leaves) & 22.50 \\
\hline
\end{tabular}

Table 2

HD vs MGH vs MHG EO yield ( $/ \mathrm{w} \%$ dry weight).

\begin{tabular}{llll}
\hline & $\mathrm{HD}^{\mathrm{a}}$ & $\mathrm{MGH}^{\mathrm{b}}$ & $\mathrm{MHG}^{\mathrm{b}}$ \\
\hline $\begin{array}{l}\text { Lavandula angustifolia Mill. } \\
\quad \text { (leaves + flowers) }\end{array}$ & 0.05 & 0.13 & 0.05 \\
$\begin{array}{l}\text { Origanum vulgare L. ssp. hirtum } \\
\quad \text { (Link) Ietswaart (leaves) }\end{array}$ & 0.75 & 0.08 & 0.73 \\
$\begin{array}{l}\text { Ocimum basilicum L. (leaves) } \\
\text { Salvia officinalis L. ssp. } \\
\quad \text { lavandulifolia (leaves) }\end{array}$ & 0.06 & 0.01 & 0.06 \\
\hline a Extraction time: 45 min. & 1.36 & 0.02 & 1.32 \\
b Extraction time: 20 min. & & &
\end{tabular}

of volatile secondary metabolites was found in the essential oils techniques, but there are some differences in their relative amounts.

In the case of Lavandula angustifolia Mill. (Table 3), the compounds extracted via the three methods are roughly the same. A higher oxygenated monoterpene content was found under MHG. These include borneol (13.72\%), linalool (8.14\%), carvone (3.91\%), cryptone (3.56\%), camphor (3.55\%) and 4-terpineol (1.57\%), whereas HD mainly leads to higher quantities of $\alpha$-cadinol (3.95\%), $\alpha$-terpineol (2.14\%), carvacrol (1.54) and phellandral (0.69\%). MGH extracts highlight a high yield in coumarin (16.59\%), 7methoxycoumarin (11.81\%) and caryophyllene oxide (4.26\%). Borneol is the most abundant compound found in the MHG profile, while coumarin is the most abundant in $\mathrm{HD}$ and $\mathrm{MGH}$.

Linalool, carvacrol and 4-terpineol are the major components in Origanum vulgare L. ssp. hirtum (Link) Ietswaart dried leaves (Table 4), but their abundance is different in HD, MGH and MHG essential oils. While linalool is the main compound in MHG (26.66\%), carvacrol appears to be the most abundant in MGH and HD (35.01\% and $26.70 \%$ respectively), and the quantity of 4-terpineol is significantly more abundant in MGH (18.05\%) than in HD (7.44\%) and MHG (4.99).

Table 3

Main components of Lavandula angustifolia Mill. L. dried material EO.

\begin{tabular}{llll}
\hline Compound & HD (\%) & MGH (\%) & MHG (\%) \\
\hline 1,8-Cineole & $\mathrm{t}$ & 1.22 & 1.35 \\
Linalool & 5.11 & 3.59 & 8.14 \\
Camphor & 1.42 & 1.69 & 3.55 \\
Borneol & 9.68 & 7.14 & 13.72 \\
4-Terpineol & 0.99 & 0.49 & 1.57 \\
Cryptone & 2.71 & 1.39 & 3.56 \\
$\alpha$-Terpineol & 2.14 & 0.74 & 1.86 \\
trans-Carveol & 0.56 & $\mathrm{t}$ & 0.66 \\
Cuminic aldehyde & 0.78 & 0.61 & 0.96 \\
Carvone & 2.03 & 2.11 & 3.91 \\
Phellandral & 0.69 & 0.39 & 0.57 \\
Carvacrol & 1.54 & 0.76 & 1.11 \\
Piperitenone & 0.47 & 0.28 & 0.43 \\
$\beta$-Caryophyllene & 0.43 & 1.29 & 0.33 \\
Coumarin & 10.52 & 16.59 & 9.41 \\
trans- $\beta$-Farnesene & 0.21 & 0.25 & 0.15 \\
$\beta$-Ionone & 0.59 & 0.45 & 0.52 \\
Dihydroactinidiolide & 1.10 & 0.94 & 0.44 \\
Caryophyllene oxide & 2.48 & 4.26 & 2.90 \\
$\alpha-C a d i n o l$ & 3.95 & 3.68 & 3.01 \\
7-Methoxycoumarin & 2.93 & 11.81 & 1.66 \\
\hline
\end{tabular}


Version définitive du manuscrit publiée dans / Final version of the manuscript published in :

Comptes Rendus Chimie (2014),vol 17, p 181-186, DOI: 1.0.1016/j.crci.2013.11.007

Journal homepage: http://www.sciencedirect.com

Table 4

Main components of Origanum vulgare L. ssp. hirtum (Link) Ietswaart dried leaf EO.

\begin{tabular}{|c|c|c|c|}
\hline Compound & HD (\%) & MGH (\%) & MHG (\%) \\
\hline$\alpha$-Thujene & 0.30 & $\mathrm{t}$ & 0.25 \\
\hline$\beta$-Pinene & 1.78 & $\mathrm{t}$ & 0.15 \\
\hline Sabinene & 1.68 & $\mathrm{t}$ & 1.63 \\
\hline$\beta$-Myrcene & 0.81 & 0.11 & 0.87 \\
\hline$\alpha$-Phellandrene & 0.14 & $\mathrm{t}$ & 0.12 \\
\hline$\alpha$-Terpinene & 2.63 & 0.95 & 1.58 \\
\hline p-Cymene & 2.48 & 0.64 & 2.32 \\
\hline$\beta$-Phellandrene & 1.14 & 0.28 & 1.11 \\
\hline$\gamma$-Terpinene & 6.02 & 4.15 & 4.51 \\
\hline trans-Sabinene hydrate & 3.57 & 1.17 & 4.57 \\
\hline$\alpha$-Terpinolene & 1.31 & 1.08 & 0.63 \\
\hline Linalol & 21.92 & 6.80 & 26.66 \\
\hline 1-Octen-3-yl acetate & 0.79 & 0.73 & 0.93 \\
\hline Borneol & 0.10 & $\mathrm{t}$ & 0.12 \\
\hline 4-Terpineol & 7.44 & 18.05 & 4.99 \\
\hline$\alpha$-Terpineol & 2.13 & 3.67 & 2.27 \\
\hline Carvacrol methyl ether & 0.11 & 0.01 & 0.12 \\
\hline Linalyl acetate & 3.93 & 0.88 & 4.50 \\
\hline Thymol & 0.20 & 0.88 & 0.27 \\
\hline Carvacrol & 26.70 & 35.01 & 22.80 \\
\hline$\beta$-Caryophyllene & 2.08 & 2.33 & 2.28 \\
\hline$\alpha$-Humulene & 0.30 & 0.32 & 0.30 \\
\hline Germacrene-D & 1.46 & 1.66 & 1.77 \\
\hline Bicyclogermacrene & 1.39 & 1.70 & 1.66 \\
\hline$\beta$-Bisabolene & 2.78 & 3.12 & 2.94 \\
\hline$\gamma$-Cadinene & 0.45 & 0.41 & 0.38 \\
\hline$\delta$-Cadinene & 0.64 & 0.83 & 0.68 \\
\hline Dihydroactinidiolide & 0.13 & 0.12 & 0.24 \\
\hline cis- $\alpha$-Bisabolene & 0.10 & $\mathrm{t}$ & 0.13 \\
\hline Viridifrorol & 0.13 & 0.24 & 0.14 \\
\hline
\end{tabular}

trans-Sabinene hydrate, $p$-cymene and linalyl acetate amounts are higher in HD and MHG but, overall, MGH extraction seemed to be more selective, although in a lower oil yield.

Linalool, eugenol and $\alpha$-cadinol are the main components in the EO of Ocimum basilicum $\mathrm{L}$. leaves. The relative amounts of the main compounds detected are reported in Table 5.

Linalool is the most abundant component in all three extracts, with preponderance in MHG (22.96\%) and in MGH (24.68\%). A similar, but not identical, trend can be seen for eugenol for which HD, MGH and MHG extracts show $13.57 \%, 15.19 \%$ and $15.93 \%$, respectively; in this case the difference between the two non-conventional techniques is very low.
Table 5

Main components of Ocimum basilicum dried leaf EO.

\begin{tabular}{lrcl}
\hline Compound & HD (\%) & MGH (\%) & MHG (\%) \\
\hline 1,8-Cineole & 2.49 & 2.38 & 6.77 \\
cis-Linalol oxide & 1.32 & 1.12 & $\mathrm{t}$ \\
trans-Linalol oxide & 1.13 & 0.93 & $\mathrm{t}$ \\
Linalool & 18.72 & 24.68 & 22.96 \\
Camphor & 0.62 & 0.56 & 0.47 \\
Borneol & 2.83 & 2.48 & 1.69 \\
$\alpha$-Terpineol & 2.03 & 1.81 & 1.10 \\
Geraniol & 1.16 & 0.52 & $\mathrm{t}$ \\
Bornyl acetate & 1.16 & 1.57 & 1.86 \\
Eugenol & 13.57 & 15.19 & 15.93 \\
$\beta$-Elemene & 1.66 & 1.11 & 1.31 \\
$\alpha$-Bergamotene & 0.94 & 1.06 & 1.13 \\
Germacrene-D & 1.91 & 1.56 & 1.75 \\
$\gamma$-Cadinene & 2.60 & 2.39 & 2.38 \\
$\alpha$-Cadinol & 9.60 & 9.88 & 9.93 \\
\hline
\end{tabular}

MW irradiation of oregano that typically has a low moisture content, may generate localized hot-spots. These high-energy microenvironments may promote the conversion of linalool to 4-terpieneol, in particular in the case of MGH. In Table 4, it is possible to observe a higher content of 4-terpineol, the typical degradation product of linalool via the pathway described in Fig. 1.

As far as $\alpha$-cadinol is concerned, extractive efficacy is quite similar for each method (HD 9.60\%, MGH 9.88\%, MHG $9.93 \%)$. The greatest yield in 1,8-cineole was detected in MHG EO (6.77\%), while HD seems to be slightly better for some alcohols, such as borneol, $\alpha$-terpineol and geraniol.

The gas chromatograms obtained from the Ocimum basilicum extracts, therefore, overlap quite extensively.

For Salvia officinalis L. ssp. Lavandulifolia dried leaf EO (Table 6), HD and MHG have comparable profiles and the same compounds were found in similar relative amounts; camphor (17.60\% and 15.31\% HD and MHG, respectively), $\alpha$-thujone (12.61\% and $12.12 \%)$ and 1,8 -cineole $(11.61 \%$ and $10.25 \%$ ) are the most abundant compounds; a higher percentage of $\alpha$-pinene was found in HD EO (5.60\% vs $2.96 \%$ MHG), while manool is more abundant in MHG (6.31\% vs $2.53 \% \mathrm{HD}$ ).

The low MGH extract yield is also reflected in the limited number of compounds present in the oil; the relative abundance of the extracted compounds is rather peculiar: in fact, viridiflorol (16.39\%) and manool (28.14\%) are by far the most concentrated.

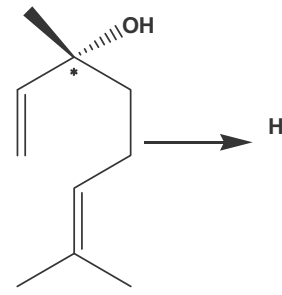<smiles>CCCC1CCC(C)(O)CCC1=C(C)C</smiles><smiles>CC=CC(C)(CO)C(C)C</smiles>

Linalool<smiles>CC1=CC[C@H](C(C)(C)O)CC1</smiles>

4-Terpineol

Fig. 1. Conversion of linalool to 4-terpineol. 
Version définitive du manuscrit publiée dans / Final version of the manuscript published in :

Comptes Rendus Chimie (2014),vol 17, p 181-1.86, DOI: 10.1016/j.crci.2013.11.007

Journal homepage: http://www.sciencedirect.com

Table 6

Main components of Salvia officinalis L. ssp. Lavandulifolia dried leaf EO.

\begin{tabular}{lclc}
\hline Compound & HD $(\%)$ & MGH (\%) & MHG (\%) \\
\hline$\alpha$-Pinene & 5.60 & $\mathrm{t}$ & 2.96 \\
Camphene & 3.72 & $\mathrm{t}$ & 2.26 \\
$\beta$-Pinene & 0.59 & $\mathrm{t}$ & 0.39 \\
$\beta$-Myrcene & 0.73 & $\mathrm{t}$ & 0.53 \\
1,8-Cineole & 11.61 & $\mathrm{t}$ & 10.25 \\
$\gamma$-Terpinene & 0.13 & $\mathrm{t}$ & 0.14 \\
$\alpha$-Terpinolene & 0.32 & $\mathrm{t}$ & 0.28 \\
$\alpha$-Thujone & 12.61 & $\mathrm{t}$ & 12.12 \\
$\beta$-Thujone & 4.60 & $\mathrm{t}$ & 4.42 \\
Camphor & 17.60 & 0.77 & 15.31 \\
Borneol & 3.62 & $\mathrm{t}$ & 3.68 \\
4-Terpineol & 0.73 & $\mathrm{t}$ & 0.40 \\
$\alpha$-Terpineol & 0.86 & $\mathrm{t}$ & 1.14 \\
Myrtenol & 0.72 & $\mathrm{t}$ & 0.65 \\
Carvone & 0.18 & $\mathrm{t}$ & 0.28 \\
Bornyl acetate & 1.49 & $\mathrm{t}$ & 1.50 \\
Carvacrol & 1.04 & 2.64 & 0.20 \\
$\gamma$-Caryophyllene & 0.08 & $\mathrm{t}$ & 0.08 \\
$\beta$-Caryophyllene & 6.07 & 5.39 & 5.39 \\
$\alpha$-Humulene & 8.33 & 7.17 & 5.77 \\
Viridiflorene & 0.36 & $\mathrm{t}$ & 0.28 \\
Caryophyllene oxide & 0.61 & 4.55 & 1.00 \\
Viridiflorol & 5.42 & 16.39 & 5.89 \\
Manool & 2.53 & 28.14 & 6.31 \\
\hline & & &
\end{tabular}

The differences in the three extraction methods confirm that microwaves are able accelerate the extraction processes and afford high quality oils.

\subsubsection{Evaluation of $M G H$ and $M H G$}

Essential oils can be classified into two main groups: terpene containing hydrocarbons, such as monoterpenes, sesquiterpenes and diterpenes; and oxygenated compounds, such as esters, aldehydes, ketones, alcohols, phenols, oxides, acids and lactones. During distillation, aromatic plants, treated with boiling water or steam, release their essential oils via the vapor distillation of immiscible liquids, namely water and EO. Thus the essential oil components, whose boiling points normally range from 200 to $300{ }^{\circ} \mathrm{C}$, are evaporated at temperatures close to that of boiling water. The amount of essential oil produced depends on four main factors: the distillation time, the temperature, the operating pressure and, most of all, the type and obviously the quality of the plant material. EO composition is strongly affected by water solubility and dielectric loss properties of the different compounds rather than their boiling point [14]. Microwaves have the peculiarity of deeply penetrating the vegetal matrix, reducing heating times and thus it is a fast and green technology for the solvent-free extraction of naturally occurring aromatic compounds.

By analyzing the results of $\mathrm{HD}$ and MGH of Origanum vulgare L., we can compare the relative abundance of linalool (a polar compound) and $\gamma$-terpinene (a non-polar compound) (Table 7).

Most likely, the presence of a continuous vapor stream during the MHG process confirms the main role of the "hydrodiffusion" phenomenon in the extract composition that may intensify the effect of microwave irradiation. With MHG it is possible to obtain EO in a more concentrated volume and shorter heating time.
Table 7

MHG "selective" extraction of linalool $v s \gamma$-terpinene in Origanum vulgare L. ssp. hirtum (Link) letswaart dried leaves.

\begin{tabular}{|c|c|c|}
\hline \multicolumn{2}{|c|}{ Linalool } & $\gamma$-Terpinene \\
\hline Structure & & \\
\hline$\%$ MHG & 26.66 & 4.51 \\
\hline$\% \mathrm{HD}$ & 21.92 & 6.02 \\
\hline $\begin{array}{l}\text { Boiling } \\
\text { point }\left({ }^{\circ} \mathrm{C}\right)\end{array}$ & 220 & 183 \\
\hline $\begin{array}{l}\text { Solubility in } \\
\text { water }(\mathrm{g} / \mathrm{L})\end{array}$ & 0.57 & 0.001 \\
\hline $\begin{array}{l}\text { Dipolar } \\
\text { moment (D) }\end{array}$ & 22 & 13 \\
\hline $\begin{array}{l}\text { Dielectric } \\
\text { constant }\end{array}$ & 1.98 & 0.72 \\
\hline
\end{tabular}

\subsection{Cost, energy and environmental impact}

The results obtained from this study have confirmed that MGH and MGH extractions are more advantageous than HD in terms of overall costs and energy. As previously reported, with our instrumentation the energies required for $\mathrm{HD}$ and $\mathrm{MGH}$ are $1.5 \mathrm{kWh}$ and $0.25 \mathrm{kWh}$ respectively, these figures correspond to a carbon footprint of 1200 and $200 \mathrm{~g} \mathrm{CO}_{2}$ for $\mathrm{HD}$ and $\mathrm{MGH}$, respectively $[11,15]$. As reported by Chemat et al. [9] the energy required to perform an extraction with MHG is $0.2 \mathrm{kWh}$ and the calculated quantity of carbon dioxide emitted is $160 \mathrm{~g}$. In a recent paper we successfully experimented a $75 \mathrm{~L}$-pilot MW reactor demonstrating the scaling up feasibility of MGH and MGH extractions [16]. Improvements in product efficiency, energy saving, process enhancement and maintenance costs, place this technology in a first rank for process intensification of plant eco-extraction.

\section{Conclusion}

The constant evolution of microwave-assisted extraction techniques strongly enhance the quality of EO and of the process itself giving it a lower environmental impact.

EO composition profiles from MHG and HD are normally super-imposable, while different selectivity occurs in MGH because it uses a lower amount of steam.

\section{Experimental}

\subsection{Plant materials}

All the plants came from the experimental centre at the Agriforfood Department of the University of Turin (Grugliasco, TO, Italy). The studied genotypes were transplanted in the field from rooted cuttings grown in greenhouses at the nursery stage in spring 2009 (Salvia 
Version définitive du manuscrit publiée dans / Final version of the manuscript published in :

Comptes Rendus Chimie (2014),vol 17, p 181-186, DOI: 1.0.1016/j,crci.2013.11.007

Journal homepage: http://www.sciencedirect.com

officinalis L. ssp. lavandulifolia) or spring 2011 (LavanLavandula angustifolia Mill., Origanum vulgare L. ssp. hirtum (Link) Ietswaart) or from seedlings grown in greenhouses at the nursery stage in spring 2011 (Ocimum basilicum L.). All cuttings were obtained from same mother plant genotype, while for sweet basil, the seeds were obtained from the same commercial seed lot. The plants were grown in the same environment, in the experimental centre $\left(44^{\circ} 53^{\prime} 11.67^{\prime \prime} \mathrm{N} ; 7^{\circ} 41^{\prime} 7.00^{\prime \prime} \mathrm{E}-231 \mathrm{~m}\right.$ a.s.l., Carmagnola, TO, Italy), and soil (sandy-loam, according to the USDA criteria). Plant density for each species was ca. 4 plant $/ \mathrm{m}^{2}$ and plants were grown according to the standard cultural practices used in the local area. Harvesting took place and was scalar according to the balsamic time from 25 June to 8 September 2011. Dried samples were obtained through an ovendrying process as set out in previous experiments and described in Tibaldi et al. [13,17]. EO content was calculated as the ratio in weight $(\mathrm{w} / \mathrm{w})$ between the cold oil collected from the burette and the original weight of the material.

\subsection{Hydrodistillation (HD)}

Essential oil extraction via HD was carried out according to Tibaldi et al. [12,13,17] with some slight modifications. The equipment used was assembled by Exacta + Optech (San Prospero, MO, Italy), namely an electrical heating mantle ( $500 \mathrm{~W}$; Electro Thermal, Thermo Scientific, Waltham, MA, USA), a 2-L Pyrex ${ }^{\circledR}$ round flask (with 1.5 L deionized water), a 4-L modified Pyrex ${ }^{\circledR}$ glass round flask filled with the plant material, a condenser and a graduated burette to collect the oil.

An aliquot of 100-300 g dried material was placed in the steam distillation system. Each distillation lasted $105 \mathrm{~min}$, including $45 \mathrm{~min}$ in which the leaves or flowers were steamed by the boiling water in the glass balloon, previous tests with a longer heating time did not increase EO yield. The 45 min distillation time started when the first drop of liquid, condensed in the cooling column, dropped into the graduated burette.

\subsection{In situ microwave-generated hydrodistillation (MGH)}

MGH was performed in a NEOS-GRMW oven (Milestone srl, Sorisole, BG, Italy).

Specific equipment and software, a videocamera and an infrared pyrometer were used.

Extractive conditions were chosen on the base of a series of preliminary tests aimed to optimize yields and to limit the formation of degradation products.

The plant material was placed in a $4 \mathrm{~L}$ beaker, covered with a polypropylene lid with a central hole connected via a glass tube to the external condenser. The latter was connected to a chiller, with a circulating fluid maintained at around $5-6{ }^{\circ} \mathrm{C}$. An aliquot of 100-300 g dried material was placed in a 4 L Pyrex ${ }^{\mathbb{R}}$ glass beaker and put in the microwave oven. Dried leaves or flowers were previously rewetted under slight steam flow by means of a commercial domestic device ('Vaporetto Polti-Italy') equipped with a flow regulator (calculated swelling: $2 \mathrm{~mL} \mathrm{~g}^{-1}$ ).
Each distillation lasted $45 \mathrm{~min}$, including $20 \mathrm{~min}$ in which the material was steamed for plant rehydration. The 20 min distillation time started when the first drop of liquid, condensed in the cooling column, dropped into the graduated burette.

\subsection{Microwave hydrodistillation and gravity (MHG)}

MHG was performed in a NEOS-GRMW oven (Milestone srl, Sorisole, BG, Italy), under conditions defined in a series of preliminary tests.

Hundred to three hundred grams of dried leaves or flowers are placed on a grid and put in a modified $4 \mathrm{~L}$ Pyrex ${ }^{\circledR}$ glass beaker with a hole at the bottom, put in the microwave oven and connected to an external round bottom flask with a condenser. The latter was connected to a chiller, with circulating fluid, maintained at around 5$6{ }^{\circ} \mathrm{C}$. Dried materials were previously rewetted under slight steam flow by means of a commercial domestic device ('Vaporetto Polti-Italy') equipped with a flow regulator (calculated swelling: $2 \mathrm{mLg}^{-1}$ ) and kept wet with this steam flow during microwave irradiation. Each distillation lasted $45 \mathrm{~min}$, including $20 \mathrm{~min}$ in which the leaves were steamed for the plant rehydration. The $20 \mathrm{~min}$ distillation time started when the first drop of liquid, condensed in the cooling column, dropped into the round bottom flask below the oven.

\subsection{Analytical apparatus}

Equipment and analysis conditions are as previously described [11]. All gas chromatographic mass spectra were recorded on an Agilent 6850 gas chromatograph (Agilent Technologies, Palo Alto, CA, USA), fitted with an MS Agilent Network 5973, which uses a $30 \mathrm{~m}$ long capillary column HP 5-MS (5\% phenyl methyl siloxane, i.d. $0.25 \mathrm{~mm}$, film thickness $0.25 \mu \mathrm{m}$ ), a 1:20 split ratio, a $250{ }^{\circ} \mathrm{C}$ injector temperature and helium as the carrier gas (1.2 $\mathrm{mL} \mathrm{min}^{-1}$ flow).

The gas chromatographic parameters were set up as follows; initial temperature $50{ }^{\circ} \mathrm{C}$, rate $3{ }^{\circ} \mathrm{C} \mathrm{min}^{-1}$, final temperature $80^{\circ} \mathrm{C}$, rate $10^{\circ} \mathrm{C} \mathrm{min}^{-1}$, final temperature $300{ }^{\circ} \mathrm{C}$, held for $10 \mathrm{~min}$. The mass spectrometric parameters were as follows; low mass 40 , high mass 800 , MS quad $150{ }^{\circ} \mathrm{C}$, MS source $230^{\circ} \mathrm{C}$.

\subsection{Sample preparation}

The samples were prepared by dissolving $0.04 \mathrm{~mL}$ essential oil in $1 \mathrm{~mL}$ chloroform.

The samples $(1 \mu \mathrm{L})$ were injected by an automatic injector (Agilent 7683B series).

The identification of products was achieved using the NIST 05 library (National Institute of Standards and Technology), Wiley Library and confirmed by comparing the retention times with those of the relative standard.

\subsection{Chemicals}

Gas chromatographic grade chloroform was purchased from Sigma Aldrich (Milan, Italy). 
Version définitive du manuscrit publiée dans / Final version of the manuscript published in :

Comptes Rendus Chimie (2014),vol 17, p 181-1.86, DOI: 10.1016/j.crci.2013.11.007

Journal homepage: http://www.sciencedirect.com

\section{Acknowledgements}

The present work was supported by the ALCOTRA project "Eco-extraction tranfrontaliere".

\section{References}

[1] M.E. Lucchesi, F. Chemat, J. Smadja, J. Chromatogr. A 1043 (2004) 323.

[2] S. Périno-Issartier, C. Ginies, G. Cravotto, F. Chemat, J. Chromatogr. A 1305 (2013) 41.

[3] F. Chemat, G. Cravotto, Microwave-assisted extraction for bioactive compounds: theory and practice, Springer Science, New York, USA 2013, XII, 238 pp.

[4] S. Rezvanpanah, K. Rezaei, S.H. Razavi, S. Moini, Food Sci. Technol. Res 14 (3) (2008) 311.

[5] F. Chemat, M. Abert-Vian, G. Cravotto, Int. J. Mol. Sci. 13 (2012) 8615

[6] A. Farhat, C. Ginies, M. Romdhane, F. Chemat, J. Chromatogr. A 1216 (2009) 5077
[7] B. Uysal, F. Sozmen, B.S. Buyuktas, Nat. Prod. Commun. 5 (2010) 111.

[8] S. Chemat, H. Ait-Amar, A. Lagha, D.C. Esveld, Chem. Eng. Process 44 (2005) 1320

[9] M.A. Vian, X. Fernandez, F. Visinoni, F. Chemat, J. Chromatogr. A 1190 (2008) 14.

[10] N. Bousbia, M.A. Vian, M.A. Ferhat, E. Petitcolas, B.Y. Meklati, F. Chemat, Food Chem. 114 (2009) 355.

[11] L. Orio, G. Cravotto, A. Binello, G. Pignata, S. Nicola, F. Chemat, J. Sci. Food Agric. 92 (2012) 3085.

[12] G. Tibaldi, E. Fontana, S. Nicola, Ind. Crops Prod. 34 (2011) 1516

[13] G. Tibaldi, E. Fontana, S. Nicola, J. Food Agric. Environ. 8 (3 \& 4) (2010) 790.

[14] P. Sandra, C. Bicchi, A. Koedam, Capillary gas chromatography in essential oil analysis, Hueting Verlag, New York, 1987.

[15] M.A. Ferhat, B.Y. Meklati, F. Chemat, Flavour Fragr. J 22 (2007) 494.

[16] A. Filly, X. Fernandez, M. Minuti, F. Visinoni, G. Cravotto, F. Chemat, Food Chem. (2013), http://dx.doi.org/10.1016/j.foodchem.2013. 10.139 .

[17] G. Tibaldi, E. Fontana, S. Nicola, J. Sci. Food Agric. 92 (2013) 580. 